\title{
LITTER PRODUCTION, DECOMPOSITION AND NUTRIENT RELEASE OF WOODY TREE SPECIES IN DHANAULTI REGION OF TEMPERATE FOREST IN GARHWAL HIMALAYA
}

\author{
Sushil Saha, G.S.Rajwar and Munesh Kumar* and Kalidas Upadhaya \\ Department of Botany Govt. Post Graduate College, Rishikesh 249201, Uttarakhand, India \\ Department of Forestry, HNB Garhwal University, Srinagar-Garhwal, Uttarakhand, India \\ (*Author for correspondence, email:muneshmzu@yahoo.com)
}

\begin{abstract}
The study has been carried out in Dhanaulity region of temperate forest of Garhwal Himalaya to understand litter production, their decomposition and concentration of nutrients release by leaf litter at different altitudes. The results indicate that the litter production with altitude in each season reduced in order of Lower $>$ middle $>$ upper altitudes, while in each altitudes the seasonal litter production reduced in order of summer $>$ rainy $>$ winter. The value of decomposition constant $(\mathrm{k})$ was reduced as $0.511,0.438$ and 0.256 at lower, upper, middle altitude respectively. The concentration of nutrients seasonally (irrespective altitude), potassium reduced from summer $(0.92 \%)$, rainy $(0.90 \%)$ and winter $(0.84 \%)$ however, phosphorus shown reverse trend with potassium as summer $(0.104 \%)$, rainy $(0.108 \%)$ and winter $(0.203 \%)$ whereas nitrogen was highest in rainy $(1.13 \%)$ followed by winter $(1.11 \%)$ and summer $(1.01 \%)$. The nutrient concentration with altitude (irrespective season), potassium increased with increasing altitudes, whereas, phosphorus and nitrogen have not shown any trend with altitude.
\end{abstract}

Keywords: Himalaya, Forest floor, Nutrient elements, NPK.

Özet

Bu çalışma Garhwal Himalaya'nın Dhanaulity bölgesindeki 1lıman kuşak ormanlarındaki ölü örtü birikimi, ölü örtü ayrışması ve böylece ölü örtüden besin maddelerinin salımı miktarlarını belirlemek amacıyla yapılmıştır. Araştrıma sonuçları, ölü örtü miktarları en yüksekten en düşüğe doğru alt>orta $>$ üst yükseltilerde olduğu ve herbir yükselti basamağında yaz>yağmurlu mevsim $>$ kış sıralamasına göre oluştuğu tespit edilmiştir. Ayrışma sabiti (k) alt, üst ve orta yükseltilerde sırasılyla $0.511,0.438$ ve 0.256 şeklinde değişmiştir. Yükseltiye bağlı olmaksızın potasyum yaz>yağmurlu mevsim $>$ kış (sırasıyla $\% 0.92,0.90$ ve 0.84 ), fosfor potasyumun tersine kış $>$ yağmurlu mevsim $>$ yaz $(\% 0.203,0.108,0.104)$ şeklinde bir değişim göstermiş, azot ise mevsimlere göre yağmurlu mevsim $>$ kiş $>$ yaz $(\% 1.13$, 1.11 ve 1.01) bir seyir izlemiştir. Mevsimlere bağlı kalmaksızın bakıldığında ise potasyum yükselti arttıkça artış göstermiş, fosfor ve azot ise yükseltiye bağlı belirgin bir değişim göstermemiştir.

Anahtar Kelimeler: Himalay, Ölü örtü, Besin elementleri, NPK.

\section{INTRODUCTION}

Litter production and nutrient cycle in terrestrial ecosystem plays an important role in turnover of nutrient and maintenance of soil fertility and productivity. The accumulation and decomposition of plant litter has been considered as complex and important factor in controlling both vegetation structure and ecosystem function (Grime, 1979). Organic matter in the mineral soil is composed of close physical and chemical relationship with the mineral function of the soil.

Litter fall on the forest floor occurs in the form of leaves, twigs, fruits, bark and small 
branches. The interactive and sequential process of litter fall, its decomposition and subsequent mineralization are essential in substaining a dynamic ecosystem. Litter of forest floor minimizes the soil erosion, runoff and increases the percolation rates as well as nutrient taken up by the tree which is held in the green foliage. A sub-sequential amount of nutrient taken up by the aboveground component of the tree is returned to the soil through litter fall. .

Litter decomposition plays a crucial role in the nutrient budget of forest ecosystems where vegetation depends mainly on the recycling of nutrients contained in the plant detritus. During this process plant nutrients become available for recycling within the ecosystem. Litter decomposition is influenced by environmental factors and also by physicochemical properties of the parts such as stem wood, leaves, root, etc. of the species studied and decomposer organisms present in the soil. Woody debris in the form of standing dead trees, fallen boles, large branches and roots is abundant in many forest ecosystems, and plays an important ecological role in the recycling of nutrients within the forest. This woody debris also reduces soil erosion, acts as a reservoir for nutrient and water storage, seed bed for plant establishment, and a habitat for fungi, bacteria, arthropods and a variety of vertebrates.

Decomposition of leaf litter is a major source of nutrients in forest ecosystems. As leaves are broken down by insect and microbial decomposers, organically-bound nutrients are released as free ions to the soil solution which are then available for uptake by plants.

Decomposition of coniferous forest is very slow. Slow rate of decay can result in the accumulation of large nutrients stocks on the soil horizons (Melillo et al., 1982). Forest release of nutrient from a forest may help an assemblage of different types of communities in the ecosystem. The rate of litter decomposition is determined by nature or plant and microclimatic conditions. The decomposer substratum performs two major functions i.e., the mineralization of essential elements and formation of soil organic matter.
However, studies on litter dynamics of tree species and its contribution to nutrient status in the soil in Dhanaulti area of Tehri Garhwal, Uttarakhand, India, have not been conducted so far; therefore, present study was undertaken with the objective of understanding Seasonal pattern of litter production, decomposition and nutrient release of woody tree species in selected forest along altitudinal gradient.

\section{MATERIALS AND METHODS}

\section{Location and climate of study area}

The present study was carried out on litter production decomposition and nutrients concentration of litter release at three different altitudes of woody tree species forest near Dhanaulti in Garhwal Himalaya of Uttarakhand. Dhanaulti is located in the Garhwal Hills between $30^{\prime} 45^{\circ} \mathrm{N}$ and $78^{\prime} 25^{\circ} \mathrm{E}$, at an altitude of $2286 \mathrm{~m}$. The forests have thick trees covers of Cedrus deodara, Quercus leucotrichophora, Rhododendron arboreum Pinus roxburgbii, etc. The moist Cedrus deodara Deodar forest (Type 12/ $\mathrm{C}_{1} \mathrm{C}$; Champion and Seth 1968) is found between altitudes $1750-2150 \mathrm{~m}$ a.s.l. Cedrus deodara is mainly observed in pure patches, while few scattered individuals of other associated species such as Quercus leucotrichophora, Pinus wallicbiana, Cupressus torulosa and Rhododendron arboreum are also found.

Three sites were selected for the present study (Figure.1) at three different altitudes i.e., upper, middle and lower (Table 1). Soils of Dhanaulti area belongs to mollisols and Satengal to inceptisols. All these polypedons are members of fine sandy loam, mixed, messic family. These soils, developed from different parent materials are in equilibrium with geogenic factors. All pedogenic processes are active in the study area. The soils are generally acidic in nature with $\mathrm{pH}$ values increasing with the depths.

The temperature in this area is cool throughout the year. The summer months are cool. The winters here are not very freezing but provide a misty view of distant mountains. The summer temperatures range from $31^{\circ} \mathrm{C}$ to $7.5^{\circ} \mathrm{C}$ while the winter temperature ranges from $7^{\circ} \mathrm{C}$ to $1^{0} \mathrm{C}$. The meteorological data of the study area is given in Figure.2. 


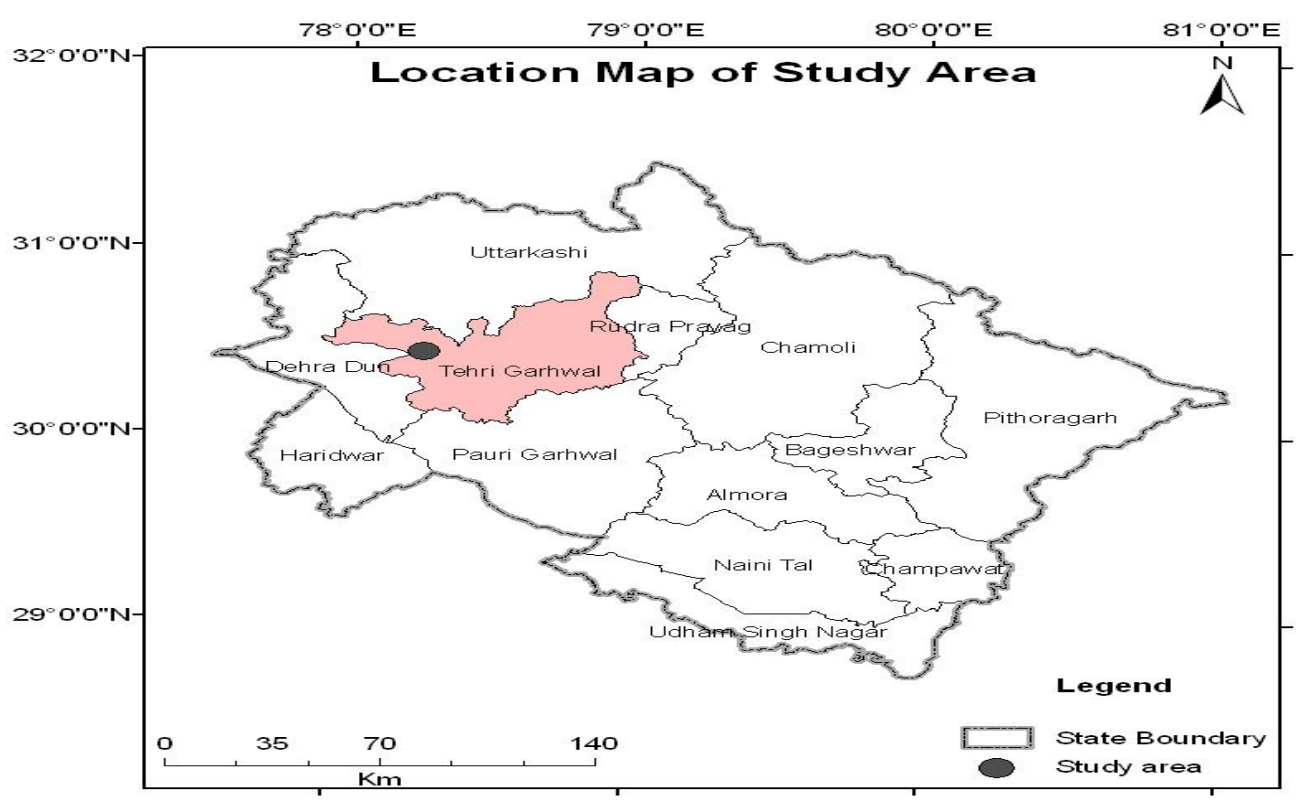

Figure.1 Location map of the study area in Uttarakhan

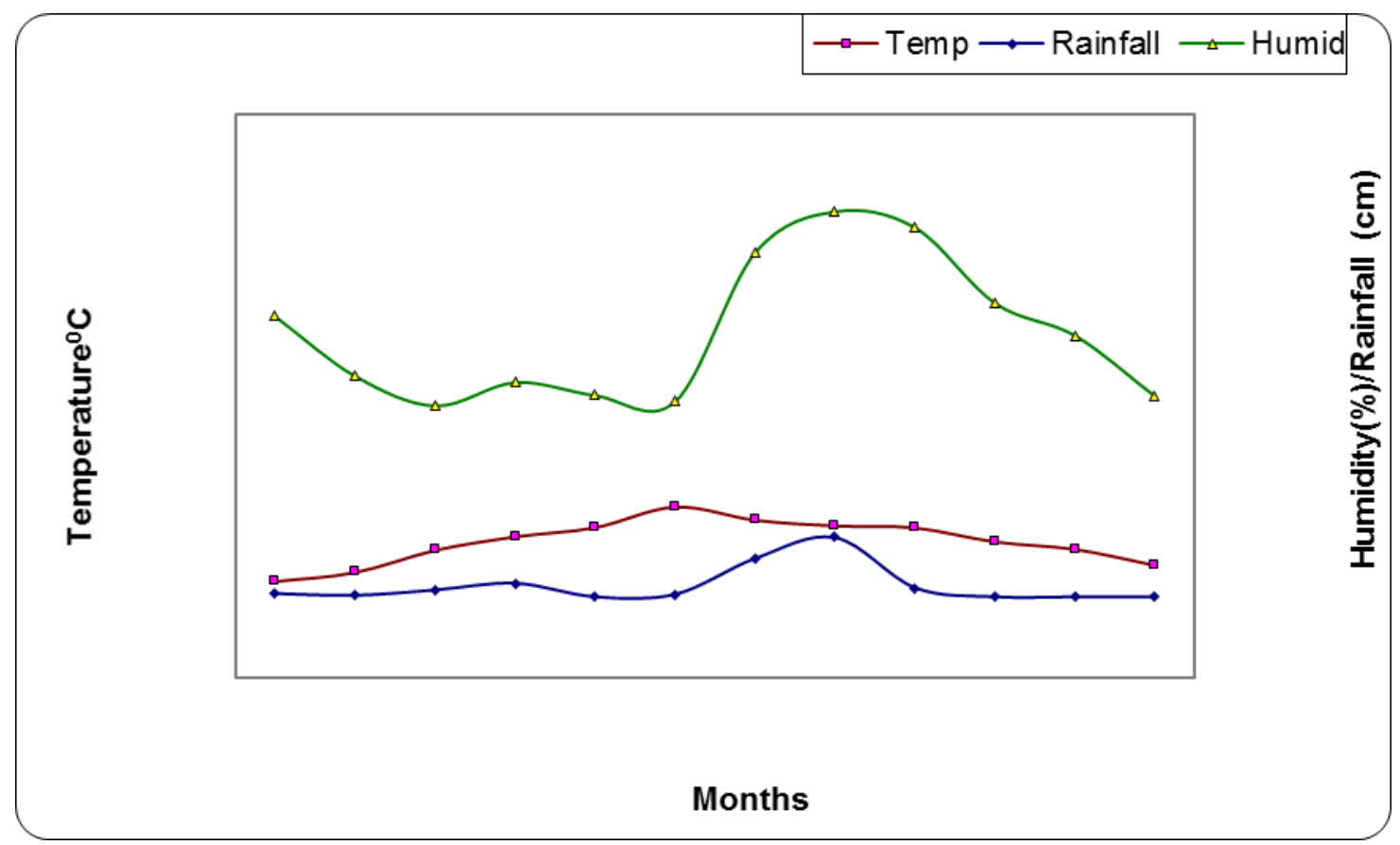

Figure.2 Meteorological data of the study area. 
Table: 1 . Details of the study area

\begin{tabular}{|l|l|l|l|l|}
\hline Location & Altitude & Georeference & $\begin{array}{l}\text { Elevation } \\
\text { (m asl) }\end{array}$ & Aspect \\
\hline \multirow{3}{*}{ Dhanaulti } & Upper & N30॰24'434"; E078॰17'894" & 2350 & North west \\
\cline { 2 - 5 } & Middle & N30॰25'209"; E078॰17'867" & 2200 & North west \\
\cline { 2 - 5 } & Lower & N30॰25'336"; E078॰17'811" & 2050 & North \\
\hline
\end{tabular}

\section{Methodology adopted \\ Litter Production}

Litter production was assessed by collecting litterfall using $1 \mathrm{~m} \times 1 \mathrm{~m}$ size litter trap at $20 \mathrm{~cm}$ high above the ground at three different altitudes. Litter was collected seasonally i.e., summer, rainy and winter. Each season was considered four months and exact after interval of 4 month of a period of 120 days the litter samples were collected and same procedure was repeated for 8 months (240 days) and 12 months (360 days).

- The collected litter was brought to the laboratory for further analysis. Dry weight of litter was determined by drying to a constant weight at $80^{\circ} \mathrm{C}$. The seasonal value of litter production for each altitude was worked out on a unit area basis $\left(\mathrm{t} \mathrm{ha}^{-1}\right)$.

\section{Litter decomposition and chemical analysis}

The rate of decomposition was estimated using standard litter-bag techniques (Bocock and Gilbert, 1957), wherein known weight of dried leaf litter samples as per availability of collected samples were placed in nylon-mesh bags $(1 \mathrm{~mm})$ and placed on the forest floor. Total nine samples were established in each altitude and same repeated for other altitudes. At a regular interval i.e., 120, 240, 360 days 3 samples were collected from each altitude and the process repeated further for each altitude and seasons. The procedure was repeated only for a period of one year.

The selected samples of litter bags were brought to the laboratory and cleaned off foreign material if any, and oven dried in paper bag to a constant weight. After drying the litter mass each bag was weighed individually. The model for constant potential weight loss (Olson, 1963) was represented by the following equation. $\mathrm{X} / \mathrm{Xo} \equiv \mathrm{e}^{-\mathrm{kt}}$ where $\mathrm{X}$ is the weight remaining at time $t$, $\mathrm{Xo}$ the original mass, ' $\mathrm{e}$ ' the base of natural logarithm, $\mathrm{k}$ the decay rate coefficient, and $\mathrm{t}$ the time. Half-life periods of decomposing litter samples were estimated from $\mathrm{k}$ values using the standard equations (Bockhiem et al., 1991). Analysis of litter sample was carried out by using standard analytical methods. Nitrogen was estimated by Kjeldahl, method. Phosphorus and potassium were determined by Molybdate-blue and Flame Photometer methods respectively.

\section{RESULTS}

\section{Litter production}

The seasonal litter production of leaf litter in different altitudes is given in Table-2. In summer season the highest litter production $\left(4.42 \pm 0.12 \mathrm{t} \mathrm{ha}^{-1}\right)$ was in lower altitude and the lowest $\left(3.57 \pm 0.27 \mathrm{t} \mathrm{ha}^{-1}\right)$ in upper altitude. In rainy season the maximum litter production was in lower altitude $\left(3.02 \pm 0.47 \mathrm{tha}^{-1}\right)$ and minimum in upper altitude $\left(2.34 \pm 0.51 \mathrm{t} \mathrm{ha}^{-1}\right)$. In winter season the highest litter production was observed in lower altitude $\left(2.23 \pm 0.52 \mathrm{t} \mathrm{ha}^{-1}\right)$ and lowest in upper altitude $\left(2.12 \pm 0.16 \mathrm{t} \mathrm{ha}^{-1}\right)$. Irrespective of altitude the annual litter production was observed maximum in summer season (4.42 $\left.\pm 0.12 \mathrm{t} \mathrm{ha}^{-1}\right)$ followed by rainy $\left(2.75 \pm 0.35 \mathrm{t} \mathrm{ha}^{-1}\right)$ and winter $\left(2.19 \pm 0.059 \mathrm{t} \mathrm{ha}^{-1}\right)$ seasons (LSD at 5\%: 0.37, 0.26 and 0.14 , respectively) (Table 2 ). 
Table: 2. Seasonal pattern of litter production $\left(\mathrm{t} \mathrm{ha}^{-1}\right)$ in different altitudes

\begin{tabular}{|l|c|c|c|}
\hline Altitude & Summer & Rainy & Winter \\
\hline Upper & $3.57 \pm 0.27$ & $2.34 \pm 0.51$ & $2.12 \pm 0.16$ \\
\hline Middle & $4.26 \pm 0.94$ & $2.86 \pm 0.71$ & $2.22 \pm 0.02$ \\
\hline Lower & $4.42 \pm 0.12$ & $3.02 \pm 0.47$ & $2.23 \pm 0.52$ \\
\hline LSD at $5 \%$ & 0.37 & 0.26 & 0.11 \\
\hline
\end{tabular}

\section{Litter decomposition}

Table-3 shows litter decomposition rate (k) for the study site in different altitudes. The value of decomposition constant $(\mathrm{k})$ was significantly high $(\mathrm{P}<0.01)$ in lower altitude (0.511) followed by upper (0.438) and middle

Table: 3. Decomposition constant $(\mathrm{k})$ and half life $\left(\mathrm{t}_{0.50}\right)$ for weight loss of leaf litter from different altitude

\begin{tabular}{|l|r|r|r|r|r|}
\hline Altitude & $\mathrm{k}$ & \multicolumn{1}{|c|}{ Std. Err. } & $\mathrm{R}^{2}$ & \multicolumn{1}{|c|}{ Adj $\mathrm{R}^{2}$} & \multicolumn{1}{|c|}{$\mathrm{t}_{0.50}$} \\
\hline Upper & 0.438 & 0.0004 & 0.9022 & 0.8140 & 585.7 \\
\hline Middle & 0.256 & 0.0001 & 0.9022 & 0.8140 & 1047.3 \\
\hline Lower & 0.511 & 0.0002 & 0.9590 & 0.9197 & 485.6 \\
\hline
\end{tabular}

\section{Nutrient release from litter \\ Winter season}

Seasonal value of percent nutrient concentration is given in Table-4. Among the nutrients nitrogen was maximum $(1.302 \pm 0.194 \% ; \mathrm{P}<0.01)$ in middle altitude and minimum $(0.996 \pm 0.002 \%)$ in the upper altitude. The phosphorus has not shown any trend with altitude, which was maximum $(0.336 \pm 0.428 \%)$ in lower altitude and minimum $(0.126 \pm 0.046 \%)$ in upper altitude $(\mathrm{P}<0.05)$. The maximum $(1.037 \pm 0.025 \%)$ and minimum $(0.64 \pm 0.106 \%)$ values of potassium were observed in upper and middle altitudes respectively $(\mathrm{P}<0.01)$.

\section{Summer season}

The value of nitrogen percent $(1.127 \pm 0.047 \% ; \mathrm{P}<0.05)$ 0in upper, middle. The highest $(0.114 \pm 0.027 \%)$ and lowest $(0.086 \pm 0.009 \%)$ values $(\mathrm{P}<0.01)$ of phosphorus were observed in middle and lower altitudes respectively, however, potassium was maximum $(1.075 \pm 0.386 \%)$ in upper altitude and minimum $(0.675 \pm 0.222 \%)(\mathrm{P}<0.01)$ in the lower altitude (Table 4).
(0.256) altitudes. Various factors are responsible for the different rates of litter decomposition such as quality of litter, temperature and moisture on which the microbial activity depends. Regular rainfall on litter gradually increases the moisture level on the top. 
Litter production, decomposition and nutrient release in Garhwal Himalaya Saha et al. 2016 4(1): 17-30

Table: 4.Seasonal percent (\%) nutrient concentration of leaf litter in different altitude

\begin{tabular}{|c|c|c|c|c|c|c|c|c|c|}
\hline \multirow[b]{3}{*}{ Altitude } & \multicolumn{9}{|c|}{ Season } \\
\hline & \multicolumn{3}{|c|}{ Rainy } & \multicolumn{3}{|c|}{ Winter } & \multicolumn{3}{|c|}{ Summer } \\
\hline & $\mathrm{N}$ & $\mathrm{P}$ & $\mathrm{K}$ & $\mathrm{N}$ & $\mathrm{P}$ & $\mathrm{K}$ & $\mathrm{N}$ & $\mathrm{P}$ & $\mathrm{K}$ \\
\hline & $1.143^{\mathrm{a}}$ & $0.117^{x}$ & $1.067 \mathrm{p}$ & $0.996^{\mathrm{b}}$ & $0.149 y$ & $1.037 \mathrm{q}$ & $1.127 \mathrm{a}$ & $0.113^{x}$ & $1.075 \mathrm{P}$ \\
\hline Upper altitude & \pm 0.040 & \pm 0.005 & \pm 0.416 & \pm 0.002 & \pm 0.013 & \pm 0.025 & \pm 0.047 & \pm 0.006 & \pm 0.386 \\
\hline & $1.297 \mathrm{a}$ & $0.122^{x}$ & $0.907 \mathrm{p}$ & $1.302^{\mathrm{a}}$ & $0.126^{x}$ & $0.64 \mathrm{q}$ & $0.966^{\mathrm{b}}$ & $0.114 y$ & $1.015 \mathrm{p}$ \\
\hline Middle altitude & \pm 0.265 & \pm 0.028 & \pm 0.311 & \pm 0.194 & \pm 0.046 & \pm 0.106 & \pm 0.319 & \pm 0.027 & \pm 0.463 \\
\hline & $0.975^{b}$ & $0.085^{x}$ & $0.733 \mathrm{P}$ & $1.032^{c}$ & $0.336^{y}$ & $0.847 \mathrm{q}$ & $0.953^{\mathrm{b}}$ & $0.086^{x}$ & $0.675^{\mathrm{r}}$ \\
\hline Lower altitude & \pm 0.021 & \pm 0.012 & \pm 0.231 & \pm 0.040 & \pm 0.428 & \pm 0.136 & \pm 0.044 & \pm 0.009 & \pm 0.222 \\
\hline
\end{tabular}

$n=5$; \pm SE. In each altitude and for each nutrient, the values with similar letters across season are not significantly different at $P<0.05$. 


\section{Rainy season}

The highest $(1.297 \pm 0.265 \%)$ value of nitrogen was in the middle altitude and lowest $(0.975 \pm 0.021 \%) \quad$ in lower altitude. The phosphorus was maximum $(0.122 \pm 0.028 \%)$ in middle altitude and minimum $(0.085 \pm 0.012 \%)$ in the lower altitude. The exchangeable potassium was maximum $(1.067 \pm 0.416 \%)$ in upper altitude and minimum $(0.733 \pm 0.231 \%)$ in the lower altitude (Table 4).

\section{DISCUSSION AND CONCLUSION}

\section{Litter production}

\section{Season-wise litter production}

In all the forest sites of Dhanaulti, the maximum (4.09 $\mathrm{t} \mathrm{ha}^{-1}$ ) litter production was observed in summer season followed by rainy $\left(2.75 \mathrm{t} \mathrm{ha}^{-1}\right)$ and winter seasons $\left(2.19 \mathrm{t} \mathrm{ha}^{-1}\right)$ The seasonal pattern of litter fall may be attributed to difference in climatic factors, such as temperature and moisture and intrinsic genetic factors (Jamaludheen and Kumar, 1999). Several workers (Sundarapandian and Swamy, 1991) have reported peaks litter fall mass in spring, summer and autumn in tropical climates. The peak litter fall in summer may be associated with physiological leaf senescence and this rhythm fits with similar studies of evergreen broadleaved forests (Lin et al., 1999; Yang et al., 2004). In present study the litterfall production has shown negative relationship with altitude. Zhou (2006) also reported decreasing trend of litterfall with increasing elevation. The significant negative relationships between elevation and litterfall productions suggest that small changes in temperature may result in significant changes in reproductive allocation.

In present study the total annual litter fall production ranged between $(8.03 \pm 0.74)$ to (9.68 $\left.\pm 1.11 \mathrm{t} \mathrm{ha}^{-1}\right)$. Rodin and Bazilevick (1967) in USSR, observed range of litterfall production from 7.0 to $10.0 \mathrm{t} \mathrm{ha}^{-1}$ in Coniferous forest. Rana et al. (1989) reported the litterfall production value of $17.3 \mathrm{t} \mathrm{ha}^{-1}$ for chir-pine forest of India. Chhabra and Dadhwal (2004) observed the litterfall production in many forests i.e., tropical evergreen $\left(6.89 \pm 0.75 \mathrm{t} \mathrm{ha} \mathrm{a}^{-1}\right)$, tropical moist deciduous forest $\left(8.93 \pm 0.64 \mathrm{t} \mathrm{ha}^{-1}\right)$, mangrove and swamp $\left(8.52 \pm 0.94 \mathrm{t} \mathrm{ha}^{-1}\right)$, tropical dry deciduous $\left(5.97 \pm 0.69 \mathrm{t} \mathrm{ha}^{-1}\right)$, tropical evergreen $\left(7.52 \pm 1.55 \mathrm{t} \mathrm{ha}^{-1}\right)$, sub-tropical montane $\left(6.70 \pm 0.72 \mathrm{t} \mathrm{ha}^{-1}\right)$ and montane temperate $\left(5.66 \pm 0.24 \mathrm{t} \mathrm{ha}^{-1}\right)$. Devi et al. (2010) reported the annual litter fall of $7.35 \mathrm{t} \mathrm{ha}^{-1}$ in tropical forest of Northeast India.

These reported values show fluctuation above and below the values of present study because litter production varies according to habit of the tree species, its age and local environmental condition (Hawkins et al., 1990; Szott and Kass, 1993). Data on litter production indicates that major portion was contributed by leaf and similar findings have also been reported (Sundarpandian and Swamy, 1999).

Seasonal fluctuations like climatic variables, exposure, soil moisture and wind velocity etc. affect variation in litterfall (Chaturvedi and Singh, 1987). Bray and Gorham (1964) found that annual litter fall production increased rapidly during stand development until canopy closer, and then remained relatively constant over a long period of time before decrease in old stands.

\section{Litter decomposition}

In the present study average decomposition (irrespective altitude and season) constant (k) was 0.402. Jenny et al. (1949) reported the decomposition rate of 0.584-1.17 for oak and 0.986-2.99 for pine forest between in USA. Similarly in USA, Witkamp (1966) reported k value of 0.015 for Quercus alba forest. Swift et al. (1979) reported $\mathrm{k}$ value of $0.21,0.77$ and 6.0 for boreal, temperate deciduous and tropical forests respectively. Pandey (1979) reported the values of decomposition rate $(\mathrm{k})$ of 0.158 for Cedrus deodarda, 0.193 for Quercus leucotrichophora and 0.139 for Cupressus torulosa forest. Upadhyay (1984) reported the decomposition rate of 0.253 for Quercus lencotrichophora, 0.274 for Quercus glanca and 0.126 for Pinus roxburgbii forests. Pant et al. (1992) reported the decomposition rate of 2.52 in Kumaon Himalaya for Quercus lencotrichophora forest. Pandey et al. (1993) reported the value of $\mathrm{k}$ as 1.35 for Pinus roxburgbii forest in India. Singh et al. (1993) reported the decomposition rate value of 0.025 for Tectona grandis forest and 
0.30-0.94 for Eucalyptus forest. Kumar et al. (2003) reported the $\mathrm{k}$ value of 3.33 for $\mathrm{a}$ deciduous forest in India. Kaushal et al. (2012) reported the value of $\mathrm{k}$ as 0.026 for Toona ciliata forest in India.

In present study the rate of decomposition was fast during rainy season and slow in winter season because weight loss was highest in rainy season. Tripathi et al. (2009) also reported litter decomposition was fast during rainy season and slow during winter season. Bala et al. reported (2010) slow rate of decomposition $(\mathrm{k}=0.1508)$ in Eucalyptus forest.

Pant and Tiwari, 1992 reported maximum decomposition during rainy season followed by winter and summer months in plantations and sand dunes areas. Many other workers (Wedderburn and Carter, 1999; Sarjubala and Yadav, 2007) also observed high rate of decomposition in rainy season because of suitable moisture, rainfall and micro-fungal population.

Decomposition essentially results in a change of state of a resource under the influence of a number of biological and abiotic factors. Initially, decomposition rate in this study was increasing with days. This could mean that different species have different rates of decomposition as reported by Muoghalu et al. (1994) and Temel (2003). High rate of decomposition recorded at the early stage and around July and August may be attributed to less moisture content in the soil, leading to high aeration, causing the aerobic organism to be active. Frioretto et al. (1998) suggested that microbial activity could be limited by litter moisture content.

Increasing decay rate indicates a faster early decomposition while increasing limit value indicates a higher fraction of slowly decomposable litter. During the decomposition of leaf litter, a vast array of chemical, physical and biological agents act upon litter constituents changing their compositions and concentrations (Berg and McClaugherty 2008).

Kumar et al. (2010) reported the faster rate of litter weight loss of during rainy season, as compared to winter was obvious in the present study. This may be attributed to prevailing locality factors. Many studies have reported an increase in rate of weight loss in relation to temperature soil/air, soil moisture, microbial load and rainfall (Gupta and Lekha, 1989; Pant and Tiwari, 1992) but none had paid heed to the importance of relative humidity during decomposition process.

\section{Chemical analysis of litter}

Nitrogen (N)

In present study the value of nitrogen (irrespective altitude and season) was $1.008 \%$. Singh et al. (1993) reported the values of nitrogen as $1.8 \%$ in Litsea deccanensis forest and $1.5 \%$ in Dalbergia sissoo forest in India. Arunachalam et al. (1998) reported the values of nitrogen $0.89 \%$ for $Q$.dealbata and $0.73 \%$ for $Q$. griffithii forest of India. Devi et al. (2009) reported the value of nitrogen as $1.02 \%$ for Quercus serrata forest of northeast India. Tripathi et al. (2009) reported the nitrogen values for Citrus reticulata (1.85\%), Alnus napalansis (1.91\%) and Pinus cassia $(1.18 \%)$ for different forests in Meghalaya. Patra et al. (2012) reported the values of nitrogen for different forest types i.e., tropical dry miscellaneous open forest $(\mathrm{N}=1.20 \%)$, closed miscellaneous forest $(\mathrm{N}=1.38 \%)$, open sal forest $(\mathrm{N}=1.72 \%)$ and closed sal forest $(\mathrm{N}=0.93 \%)$.

Chemical composition of litter, which changes with type of plant community, influences structure and activity of microbial communities inhabiting soils (Kutsch and Dilly, 1999), and biological and physicochemical properties of top soil (Heal and Dighton, 1986). Knowledge of litter production is important when estimating nutrient turnover, $\mathrm{C}$ and $\mathrm{N}$ fluxes, and $\mathrm{C}$ and $\mathrm{N}$ pools in different ecosystems. Release of nutrients not only depends upon litter composition but also upon soil type, microbial communities and soil properties (Kutsch and Dilly, 1999; Scholes and Walker, 1993). Lower content of highly mobile nitrogen might be due to leaching with rain water, and lower $\mathrm{Mg}$ content in leaf litter possibly reflected the chlorophyll decay which confirms findings by Kava'ova and Acek, (2003). More nitrogen is returned through litter fall than any other element in this study, which was similarly observed by other studies (Muoghalu et 
al., 1993; Hermansah et al., 2002). Generally, tropical forests have higher concentration of nitrogen than comparable temperate forests due to higher concentration of this element in leaf litter. Fluxes of nitrogen associated with leaf fall are an important component of the internal $\mathrm{N}$ cycle of a forest ecosystem. Reich et al. (1992) and Aerts (1996) suggest that they are determined largely by the physiological and anatomical characters of the main tree species. The concentration of plant nutrients in litterfall is important because it influences both the rate of decomposition and the amount of nutrient released to the soil during such decomposition. Therefore, the quality of litterfall, particularly $\mathrm{N}$ was probably affected by the concentration of $\mathrm{N}$ in the soil and also due to the nature of the tree which is a leguminous plant capable of fixing nitrogen. The nutrient flux within the study site had nitrogen with highest flux and this may be presumably due to the tree species, a leguminous plant.

\section{Phosphorus (P)}

In present study the value of phosphorous (irrespective altitude and season) was $0.139 \%$. Singh et al. (1993) reported the values of phosphorus amounting to $0.16 \%$ in Litsea deccanensis forest and $0.04 \%$ in Dalbergia sissoo forest in India. Arunachalam et al. (1998) reported the values of phosphorus $0.06 \%$ for $Q$. dealbata and $0.05 \%$ for $Q$. griffithii forest of India. Tripathi et al. (2009) reported the values of phosphorus in different forests i.e., Citrus reticulata $(0.22 \%)$, Alnus napalansis $(0.22 \%)$ and Pinus cassia (0.096) in Meghalaya. Patra et al. (2012) reported the phosphorus values in different forest types i.e., tropical dry miscellaneous open forest $(\mathrm{P}=0.17 \%)$, closed miscellaneous forest $(\mathrm{P}=0.36 \%)$, open sal forest $(\mathrm{P}=0.34 \%)$ and closed sal forest $(\mathrm{P}=0.27 \%)$.

Variation in concentrations of nutrient elements reflected the seasonal trend in the amount of litter fall and the concentration of elements in the litter as observed by Muoghalu et al. (1993). Potassium, phosphorus and Mg had their maximum concentrations in the dry season, although Klinge and Rodrigues (1968) recorded a high concentration of phosphorus and potassium in litter in the wet season.

\section{Potassium (K)}

In present study the value of potassium (irrespective altitude and season) was $0.888 \%$. Singh et al. (1993) reported the values of potassium amounting to $0.8 \%$ in Litsea deccanensis forest and $0.7 \%$ in Dalbergia sissoo forest in India. Tripathi et al. (2009) reported the values of potassium in different forests i.e., Citrus reticulata (1.58\%), Alnus napalansis (1.71\%) and Pinus cassia $(0.97 \%)$ in Meghalaya. Patra et al. (2012) reported the values of potassium in different forest types i.e., tropical dry miscellaneous open forest $(K=0.29 \%)$, closed miscellaneous forest $(K=0.40 \%)$, open sal forest $(K=0.32 \%)$ and closed sal forest $(\mathrm{k}=0.35 \%)$.

The maximum concentration of these elements was in the dry season. High potassium content could be due to lack of rainfall during these months. Potassium is easily leached from leaves and litter by rain water (Egunjobi, 1971; Egunjobi and Fasehun 1972). The amount of nutrient flux corresponded with the dry weight of litter produced. This is in accordance with the observation by Frioretto et al. (1998) that microbial activity can be limited by litter moisture content. However, where there is high concentration of aerobic organism, nutrient release through decomposition will still continue because these organisms are active when there is high aeration. The result indicated higher rate of $\mathrm{P}, \mathrm{K}$ and $\mathrm{N}$ release. Similar trend has been observed by Singh (1980) in the humid tropical forest. This rapid release could be attributed to the rapid loss of water soluble compounds. Potassium and phosphorus are usually constituents of metabolites enzyme system of the plant sap. Early immobilization of $\mathrm{N}$ and $\mathrm{P}$ and subsequent decrease in concentration following mass loss has been found in other studies (Sharma and Ambasht, 1987; Palm and Sanchez, 1990).

The nutrient accumulation could also be from falling litter, precipitation, through fall, stem flow, the soil substrate, and from the growth of fungal hyphae (Swift et al., 1979). High rate of nitrogen release from the leaf litter of Leucaena could be attributed to the influence of soil microarthropods. The sudden increase in nutrient remains at the end of the studies for 
nitrogen could indicate that soil $\mathrm{N}$ was being immobilized by the decomposing organism (Alfred and O'sullivan 2001).

Generally, the net accumulation of nutrient remaining at the end of the study may also suggest that some microorganisms acting on the resource fed, died and decomposed on the litter, thus, increasing the nutrient quality. In decomposing litter, the chemical component may be regarded in a certain sequence, reflecting a succession of micro-organisms with different saprotrophic abilities (McClaugherty and Berg, 1987; Temel, 2003). Frankland (1992) and Cox et al. (2001) attributed litter decomposition and release of $\mathrm{N}, \mathrm{P}, \mathrm{K}, \mathrm{Ca}$ and $\mathrm{Mg}$ to the influence of microarthropods and earthworms. Decomposition is important because plant production depends on the recycling of nutrients within the system; recycling depends on the decomposition of organic matter and release of the nutrient it contains. It has long been recognized that soil fauna affects decomposition mainly through the combination of substrates, and influencing microbial activity (Tian et al., 1998). The results agree with other workers' conclusion that litter decomposition rate is more related to litter quality than to environmental conditions (Facelli and Pickett, 1991; De Santo et al., 1993, Temel, 2003).

The variation in nitrogen $\%$ due to seasons is not significant i.e., the seasonal effect on nitrogen of decomposed litters is insignificant. However it may be seen, that nitrogen $\%$ increases from summer to rainy season and decreased from rainy season to winter (Figure-3).

The variation in nitrogen $\%$ with altitudes is highly significant $(\mathrm{P}<0.01)$. It is highest $(1.196 \%)$ in the lower altitude and reduced with altitude where minimum $(0.962 \%)$ value was reported in the upper altitude (Figure4).

The variation in potassium due to seasons is not significant i.e., there is no seasonal effect on potassium of decomposed litters. However it may be seen that potassium decreases after summer and was reported minimum in winter (Figure-5). The variation in
$\mathrm{K}$ with altitudes is highly significant. It is highest $(1.156 \%)$ in the lower altitude and lowest (0.632) in the upper altitude (Figure-6). This shows that with increase in altitude the potassium percent in litter decreases.

The variation in phosphorus $\%$ due to seasons is not significant i.e., the seasonal effect on phosphorus of decomposed litters is insignificant. The variation in phosphorus with altitudes is not significant. It is highest $(0.175 \%)$ in the middle altitude and minimum (0.09\%) in the upper altitude (Figure-7).

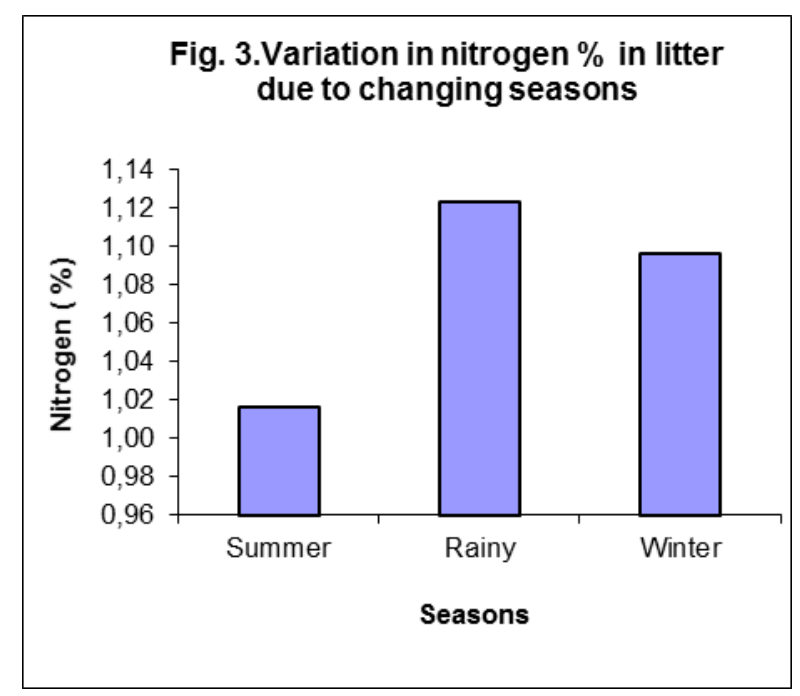

Fig.4 Variation in nitrogen \% in litter due to changing altitudes

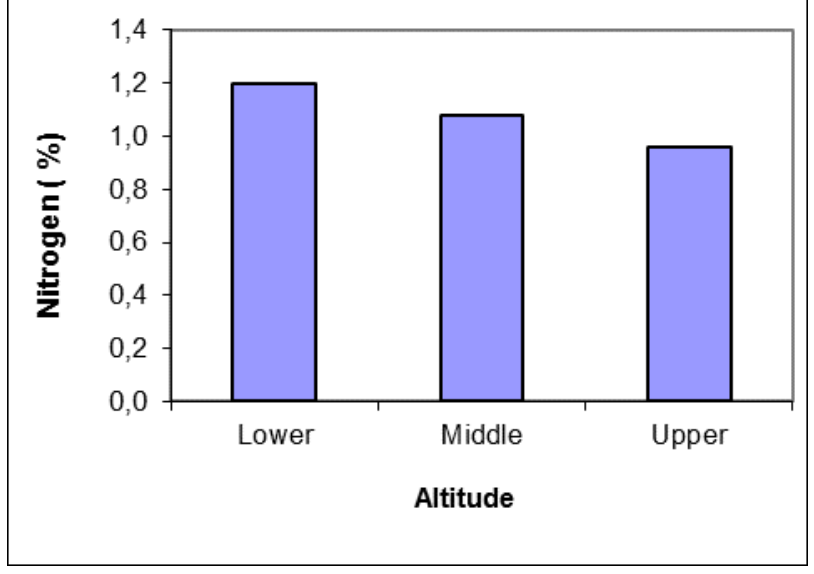



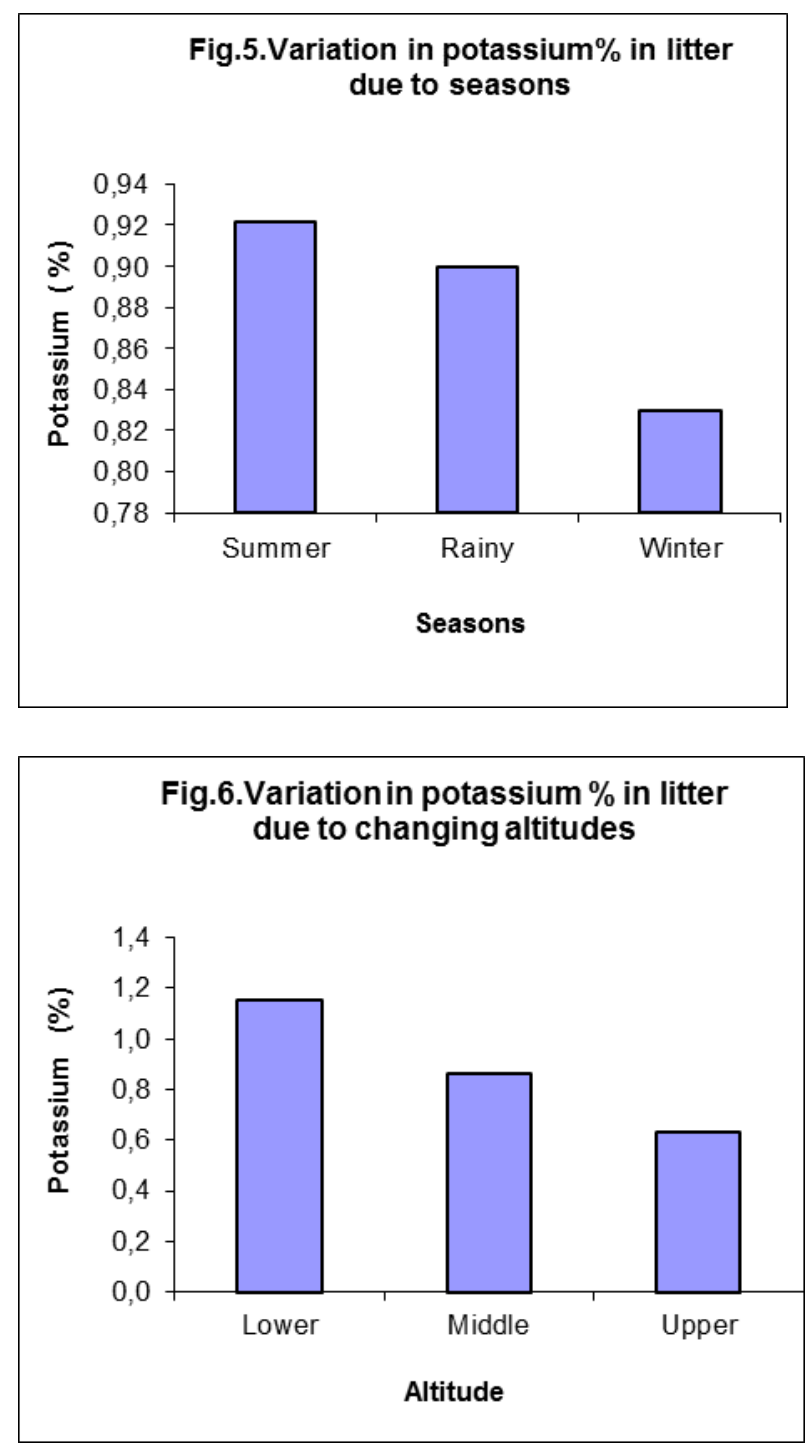

Fig.7.Variation in phosphorus $\%$ in litter due to changing seasons

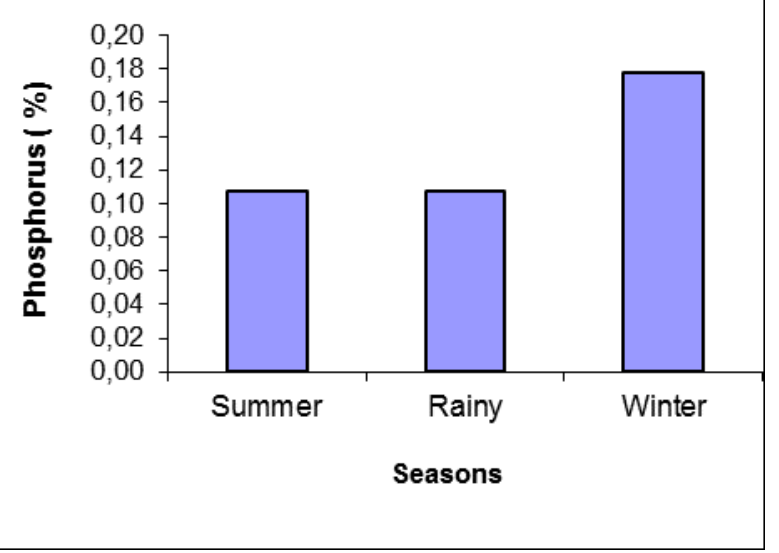

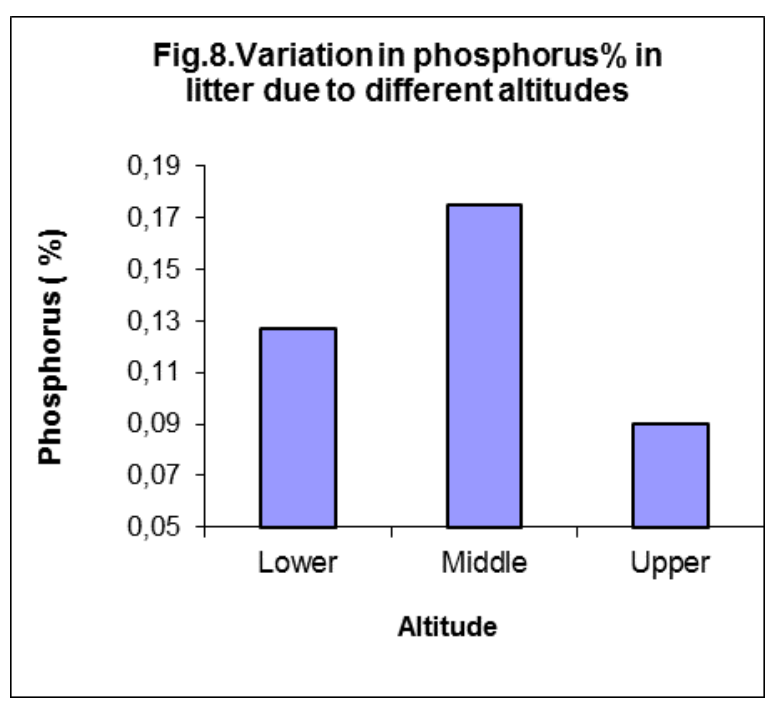

The annual return of nutrient irrespective of altitude was observed in order of $\mathrm{N}>\mathrm{K}>\mathrm{P}$. The concentration of nitrogen was in order of middle altitude> upper altitude $>$ lower altitude. Similarly the concentration of phosphorus was in order of lower altitude $>$ upper altitude $>$ middle altitude and the concentration of potassium was in order of upper altitude $>$ middle altitude $>$ lower altitude.

\section{References}

Alfred, E. H. and O'Sullivans, J. N. O. 2001. Leaf litter decomposition of Piper aduncum, Gliricidia sepium and Imperata cylindrical in the humid lowland of Papau New Guinea. Pl. Soil 230: 115-124.

Arunachalam, K., Maithani, Pandey, H.N. and Tripathi, R.S. 1998. Leaf litter decomposition and nutrient mineralization patterns in regrowing stands of a humid subtropical forest after tree cutting. Forest Ecology and Management. 109:151-161.

Berg, B. and McClaugherty, C. 2008. Plant litter Heidelberg: Springer Wieder R.K, Lang G.E. 1982. A critique of the analytical methods used in examining decomposition data obtained from litter bags. Ecology. 63:1636-42.

Bockheim, J.G., Jepsen, E.A. and Heisey, D.M. 1991. Nutrient dynamics in decomposing leaf litter of four tree species on a sandy soil in north western Wisconsin, Canadian Journal of Forest Research. 21: 803-812. 
Bocockk, L. and Gilbert O.J.W. 1957. The disappearance ofleaflitter under different woodland conditions. PI. Soil. 9 : 179-185

Bray J.R. and Gorhamm, E. 1964. Litter production in the forest of the world 100-157: In Advances in Ecological Research, Cragg, J.B. (ed) Academic Press lnc. (London) Ltd.

Chabra, A. and dadhwal, V.K.2004. Assesment of major pools and fluxes of carbon in Indian forest. Climatic Changes.64:341-360.

Champion, H.G. and Seth, S. K. 1968. The forest types of India. Govt. of India, New Delhi.

Chaturvedi, O.P and Singh, J.S. 1987. The structure and function of pine forest in central Himalaya. II. Nutrient dynamics. Annals of Botany. 60: 53-67.

Cox. P., Wilkinson, S.P. and Anderson, J.M. 2001. Effects of fungal inocula on the decomposition of lignin and structural polysaccharides in Pinus sylvestris litter. Biol.Fertil. Soils 33:246- 51.

De Santo, A. V., Berg, B., Rutigiliano, F. A., Aleani, A. and Frioretto A. 1993. Factors regulating early stage of decomposition of needle litters in five different coniferous forests. Soil Biol. Biochem. 25: 1423-1433.

Devi A.S., Yadava P.S. (2007) Wood and leaf litter decomposition of Dipterocarpus tuberculatus Roxb. in a tropical deciduous forest of Manipur, Northeast India. Current Science. 93: 243-246.

Devi, N. Bijayalaxmi and P.S. 2010. Yadava Influence of climate and litter quality on litter decomposition and nutrient release in subtropical forest of Northeast India. Journal of Forestry Research, 21(2): 143-150.

Egunjobi, J. K. 1971. Ecosystems processes in a stand of Ulex europaeus L. (11) recycling of chemical elements in the ecosystem. J. Ecol. 59 669-678.

Egunjobi, J. K. and Fasheun, F. E. 1972. Preliminary observations on the monthly litterfall and nutrient content of Pinus caribea leaf litter. Niger. J. Sci. 6(1).

Facelli, J.M. and Pickett, S.T.A. 1991. Plant litter: its dynamics and effects on plant community structure. Botanical Review: 57:(1-33).

Frankland, J. C. 1992. Mechanisms in fungal succession. In The fugal community: Its organization and role in the ecosystems, 2nd edn. (G. C. Carroll and D. T Wicklow ed.), pp. 383-401. Marcel Dekker, New York.

Frioretto, A., Musacchio, G. Andolfi. and De Santo, A. V. 1998. Decomposition dynamics of litters of various pine species in a Corsican pine forest. Soil Biol. Biochem. 30: 721-727.

Gupta, S.R. and Lekha, A. 1989. Decomposition and carbon turn over in grassland, forest and agricultural systems in a dry subhumid regions.p 131-168. In: J. S. Singh and Gopal B (Eds) Perspectives in ecology.Jagmander Book Agency, New Delhi.

Hawkins, R. Sembiring, H. Lubis, D. 1990. The potential of alley cropping in upland of east and central Java. UACP, Department of agriculture, Salatiga, Indonesia.

Heal, O.W. and Dighton, J. 1986. Nutrient cycling and decomposition in natural terrestrial ecosystems. Pp. 14-73 in Mitchell, M. J. \& Nakas, J. P. (eds.) Microflora and faunal interactions in natural and agro ecosystems. Nijhoff and Junk, Dordrecht.

Hermansah, A. Z., Tsugiyuki, M. and Toshiyuki. W. 2002. Litter fall and nutrient flux in tropical rain forest. West Sumatra, Indonesia 17th WCSS, 14-21 Aug. 2002. Thailand. Symposium No. 1125. Paper No. 1125.

Jamaludheen, V. and Kumar M. B. 1999. Litter of multipurpose trees in Kerala, India: variations in the amounts, quality, decay rates and release of nutrients. Forest Eclogy Management. 115: 1- 11.

Jenny, H., Gessel, S.P. and Bingham, F.T. 1949. Comparative study of decomposition. Soil Science. 68:419-432.

Kaushal, R., Verma, K.S., Chaturvedi, O.P. and Alam, N.M. 2012. Leaf litter decomposition and nutrient dynamics in four multipurpose tree species.Range Mgmt. and Agroforestry 33(1): 20-27.

Kava'ova, M. and Acek, S. V. 2003. Mountain Norway spruce forests. Needle supply and its nutrient content. J. For Sci. 49(7): 327332.

Kumar, M., Joshi, M. and Todaria, N.P. 2010. Regeneration status of a sub-tropical Anogeissus latifolia forest in Garhwal Himalaya, India. Journal of Forestry Research. 21(4): 439-444.

Kumar, P., Rajwar, G.S. and Sharma, A. 2003. Litter decomposition of two tree species in a tropical deciduous forest of Garhwal Himalaya. Pages 44-58, In: Bisht, N.S. (Editor) Litter Dynamics in Himalaya. Niharika Publication, Pauri, Garhwal.

Kutsch, W. L. and Dilly, O. 1999. Ecophysiology of plant and microbial interactions in terrestrial ecosystems. Pp. 74-84 in Beyschlag, W. and 
Steinlein, T. (eds.) Okophysiologie pflanzlicher Interaktionen. Bielefelder Okologische Beitr" age 14.

Lin, C.H., R.L. Mc Graw, M.F., George and H.E. Garrett. 1999. Shade effects on forage crops with potential in temperate agroforestry practices. Agroforestry Systems 44: 109-119.

McClaugherty, C.A. and Berg, B. 1987. Cellulose, lignin and nitrogen concentrations as rate regulating factors in late stages of forest litter decomposition. Pedobiologia 30:101112.

Melillo, J.M., Aber, J.D. and Muratose, J.R. 1982. Nitrogen and lignin control of heartwood leaf litter decomposition dynamics. Ecology. 63: 621-626.

Muoghalu, J. I., Adeloye, O. M. and Balogun, R. T. 1994. Litter decomposition and inorganic element dynamics in a secondary rainforest at Ile-Ife. Nigeria. Afr. J. Ecol. 32: 208-221.

Muoghalu, J. I., Akanni, S. O. and Eretan O. O. 1993. Litter and nutrient dynamics in a Nigerian rainforest seven years after a ground fire. J. Veg. Sci. 4: 325-328.

Olson, J.S. 1963. Energy storage and the balance of produces and decomposition in ecological system Ecology, 44:322-331.

Palm, C. A. and Sanchez, P. A. 1990. Decomposition and nutrient release patterns of the leaves of three tropical legumes. Biotropica 22: 330338.

Pant, S.C. and Tiwari, S.C 1992. Litter fall and litter decomposition in a montane oak forest of Garhwal Himalaya. Tropical Ecology. 33 (1): 103- 109.

Patra, A.K. and Pande P.K. 2012. Litter, nutrient dynamics and forest floor management in Sal and miscellaneous forest in Satpura plateau (India). Indian Forester 138(3): 219228.

Rana, B.S., Singh, S.P. and Singh, J.S. 1989. Biomass and primary productivity in Central Himalayan forests along the altitudinal gradient. For. Ecol. Manage., 27: 199-218.

Reich P. B., Walter M. B. and Ellsworth D. S. 1992. Leaf life-span in relation to leaf, plant and stand characteristics among diverse ecosystems. Ecol. Monogr. 62: 365-392.

Rodin, L.E. and N.I. Bazilevich. 1967. Production and mineral cycling in Terrestrial vegetation (Eng. Transl. G.E.Fogg) Oliver and Boyd, Edinburgh and London pp. 288.

Scholes, R. J. and Walker, B. H. 1993. An African savanna - synthesis of Nylsvley study.
Cambridge University Press, Cambridge. 306 pp.

Sharma, A. and Ambasht, R.S. 1987. Litter fall, decomposition and nutrient release in an age sequence of Alnus nepalensis plantation stands in the eastern-Himalaya. Journal of Ecology, 75: 997 -1000.

Singh, J. 1980. Studies on structural and functional aspects of two subtropical humid forest type in Meghalaya. (PhD Thesis.) North-Eastern Hill University, Shillong, India.

Singh, O., Sharma, D.C. and Rawat, J.K. 1993. Production and decomposition of leaf litter in Sal, Teak, Eucalyptus and Poplar forests in Uttar Pradesh. Indian Forester. 119(2): 112-121.

Sundarapandian, S. M. and P. S. Swamy. 1999. Litter production and leaf litter decomposition of selected tree species in tropical forests at Kodayar in the Western Ghats, India, For. Ecol. Manage., 123, 231-244, doi: 10.1016/S0378-1127(99)00062-6.

Swift, M. J., Heal, O. W. and Anderson J. M. 1979. Decomposition in terrestrial ecosystems. Blackwell, Stafford, UK. 372 pp.

Szott L.T. and Kass, D.C. 1993. Fertilizers in agroforestry. Agro. Syst., 23: 157-176.

Temel, S. 2003. Litter decomposition of Picea orientalis, Pinus sylvestris and Castanea sativa trees crown in Artvin in relation to their initial title quality variables. Turkey Agric. For., 27: 23-243.

Tian, G., Adejuyigbe, C. O., Adeoye, G. O. and Kang, B. T. 1998. Role of soil microarthropods in leaf decomposition and $\mathrm{N}$ release under various land-use practices in the humid tropics. Pedobiologia. 42: 33-42.

Tripathi, O. P., Pandey, H. N. and Tripathi, R. S. 2009. Litter production, decomposition and physico-chemical properties of soil in 3 developed agroforestry systems of Meghalaya, Northeast India. African Journal of Plant Science.3 (8):160-167.

Upadhyay, V.P. 1984. Leaf litter decomposition in certain forest ecosystems of Kumaun Himalaya. Ph.D. Thesis, Kumaun University, Naintal.

Wederburn, M.F. and Carter, J.1999. Litter decomposition by four tree types for use in silvipastrol system. Soil Biol.Biochem.47:194-201.

Yang, Y.S., Chen, Y.X., He, Z.M. and Guo, J.F. 2004. Comparatively study on litter properties between plantations of Fokienia hodginsii 
Litter production, decomposition and nutrient release in Garhwal Himalaya Saha et al. 2016 4(1): 17-30

and Cunninghamia lanceolata. Sci. Sil. Sin.

40: 2-9

Zhou, G. et al., 2006 Old-growth forests can accumulate carbon in soils. Science.314: 1417.

Submitted: 11.09 .2015

Accepted: 02.05.2016 